\title{
アルミニウム基材上への高機能化コーティング
}

\author{
國次 真輔 ${ }^{\mathrm{a}}$, 日野 実 ${ }^{\mathrm{a}}$, 野村 博郎 $^{\mathrm{b}}$ \\ a 岡山県工業技術センター ( T 701-1296 岡山県岡山市北区芳賀 5301) \\ ${ }^{\mathrm{b}}$ 松山技研株)( ₹ 386-0407 長野県上田市長瀬 1107)
}

\section{High Functional Coatings on Aluminum Alloy}

\section{Shinsuke KUNITSUGU ${ }^{\mathrm{a}}$, Makoto HINO ${ }^{\mathrm{a}}$ and Hirorou NOMURA ${ }^{\mathrm{b}}$}

\author{
${ }^{a}$ Industrial Technology Center of Okayama Prefecture(5301, Haga, Kita-ku, Okayama-shi, Okayama 701-1296) \\ ${ }^{\mathrm{b}}$ Matsuyama Giken Co., Ltd.(1107, Nagase, Ueda-shi, Nagano 386-0407)
}

Keywords : DLC, Ni-P, Al Alloy, Scratch Test, Micro Indentation Test, Adhesion

\section{1.はじめに}

DLC (ダイヤモンドライクカーボン)はすぐれた耐摩耗性, 摺動性を有しており, 高機能コーティングとして自動車・産 業用機械部品や金型・工具などに広く利用されている。一方 で省資源・省エネルギー社会を目指した材料開発が多分野で 行われており, 軽量なアルミニウム合金への DLC 成膜の要 求がますます高まっている。

しかしながら，アルミニウム合金基材への DLC 膜の適用 は容易ではない。DLC 膜がアルミニウム合金切削工具用コー ティングとして多く利用されているのは, DLC とアルミニ ウムとの反応性がそしいためであり，この特性が密着性の確 保を困難にしている。また，アルミニウム合金のような軟質 基材の場合, 基材と DLC 膜との界面での密着強度を確保で きたとしても軟質な基材の変形に追随できないと, 薄い DLC 膜は容易に剥離を起こしてしまう。したがって, 基材 の強化が密着性向上のカギとなる。

一般に, 皮膜の密着性を改善するためには, 皮膜の多層化 や中間層の導入, 基材の強化などが有効であり, これらを組

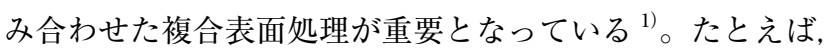
著者らは SUS304 基板上の DLC 成膜において, 中間層とし て CrN 膜を施すことにより, 密着性の指標であるスクラッ チ試験の剥離臨界荷重が飛躍的に向上されることを示した ${ }^{2)}$ 。 SUS304 基板を浸硫窒化により強化すればさらに向上する。 したがって，アルミニウム合金の場合も複合表面処理を適用 する必要があるが, 鉄鋼材料のように浸炭や窒化などの基材 強化が容易ではない。したがって中間層を導入しなければな らない。

アルミニウム合金の表面硬化処理技術としては, ハードク ロムなどの硬質めっき, アルマイトなどの陽極酸化処理, 肉 盛, 溶射, レーザ・電子ビーム・TIG などの表面焼入れ, 蒸 着・CVD・PVD 法など真空バッチプロセスが挙げられる。 DLC 膜は, CVD や PVD 法など真空バッチプロセスで成膜
されるため, DLC 膜の下地処理膜に要求される性能は, 高 硬度のみならず, 平滑性が高い, 久陥が少ない, 耐熱性が高 い(成膜中のデガスと基材の軟化を生じない)ことが挙げられ る。

\section{2．アルミニウム基材上への DLC 複合化処理例}

アルミニウム合金上への DLC 膜を適用するための複合化 処理例を紹介する。A7075 基材上に中間層として PVD 法で あるスパッ夕 $\mathrm{Cr}-\mathrm{N}$ 膜を用いた場合 ${ }^{3)}, \mathrm{CrN}$ 膜および DLC 膜 の硬さと膜厚を最適化することにより密着性が大幅に改善し た。密着性が低い組み合わせにおいては, 有限要素法による 解析で, DLC と CrN の界面に大きなせん断応力が発生する 荷重領域があることも判明した。

スクロール圧縮機におけるスクロール摺動部材の摺動特性, 耐焼付き性向上を目的として，アルミニウム合金上への DLC 膜を検討し, 中間層に無電解 Ni-P めっきを適用するこ

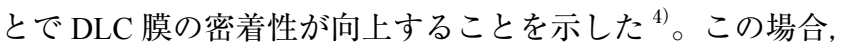
スクラッチ試験による剥離臨界荷重は, Ni-P 層厚さととも に増大した。さらに, 摩擦摩耗試験の結果, 窒化処理した鉄 鋼材に対して優れた摺動性と耐摩耗性および低い相手攻撃性 を示すことがわかった。

最近では，アルミニウム合金上へ $\mathrm{W}$ 微粒子ピーニング処 理により化合物層を形成することで基材強化を行い, DLC 膜の密着性を向上させ, エンジンピストンへの適用に成功し

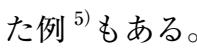

このように, アルミニウム合金は, 浸炭や窒化といった鉄 基材では可能な拡散浸透処理による基材強化ができないため, CVD 法, PVD 法や湿式めっき法などを中間層として付与す ることが密着性向上に有効である。

本稿では, 中間層として Ni-P めっき膜を用いた DLC 膜を 作製し, 中閔層の膜質が密着性にどのように影響を及ぼすか 調查した結果 ${ }^{6)}$ を解説する。 


\section{A7075 基材への Ni-P/DLC 複合膜の適用}

\section{1 試料作製}

Ni-P 無電解めっき皮膜は, アモルファス構造であるが熱 処理によって結晶化するとともに高硬度化することが知られ ている ${ }^{7)}$ 。この性質を利用すれば，熱処理による基材強化を 図ることができ，DLC 膜の密着性の向上が期待できる。基 材としては，アルミニウム合金の中で高強度材として知られ るA7075を取り上げた。一方で, 高温における基材の軟化 は不可避であり, 真空プロセス中での温度上昇による基材の 軟化が懸念される。また，A7075の合金元素として添加され ているZnの昇華も懸念される。

A7075 基板上に Ni-P を下地処理として Ni-P/DLC 多層膜を 作製し, DLC 皮膜の密着性に及ぼす Ni-P めっきの熱処理温 度の影響について検討した。

まず，A7075-T6 基板をアルカリおよび酸洗浄後，ダブル ジンケートを施し, 市販の無電解 Ni-P めっき浴 ( $\mathrm{P}$ 濃度 : 9 〜 10\%) を用いて Ni-P めっき皮膜を形成した。この試料を, 真空加熱イメージ炉により，10 $0^{-5} \mathrm{~Pa}$ 台までターボ分子ポンプ により真空排気した後，150〜 $400{ }^{\circ} \mathrm{C}$ でそれぞれ 1 時間，熱 処理を行った。ついでUBMS（アンバランスドマグネトロン スパッタリング)装置により， $\mathrm{Cr}$ 系中間層を形成した後, DLC 膜を形成し Ni-P/DLC 複合処理皮膜とした(図 1)。Ni-P めっき皮膜の膜厚は $21 \mu \mathrm{m}, \mathrm{DLC}+\mathrm{Cr}$ 系中間層は $2 \mu \mathrm{m}$ と した(図 2)。
3. 2 熱処理温度による Ni-P / DLC 複合皮膜の膜質変化

図 3 にNi-Pめっき膜の熱処理後のXRD結果を示す。 $250{ }^{\circ} \mathrm{C}$ までの熱処理ではブロードなピークしか見られないこ とからアモルファス構造であると考えられるが, $300{ }^{\circ} \mathrm{C}$ 以上 の熱処理により $\mathrm{Ni}_{3} \mathrm{P}$ および $\mathrm{Ni}$ 由来のシャープなピークが観 察されることから, 結晶化していることがわかる。図 4 に熱 処理温度による Ni-P めっきおよびA7075 母材の硬さの変化 を示す。Ni-P めっきは, As-depo の状態では 500 HV0.025 で あり, $250{ }^{\circ} \mathrm{C}$ までは熱処理温度の増加とともに除々に増加し た。しかし， $300{ }^{\circ} \mathrm{C}$ 以上の熱処理では結晶化により 1050 HV0.025 と急激に増加した。一方，母材の硬さは，熱 処理なしでは $185 \mathrm{HV} 1$ と高い硬度を示し, $150{ }^{\circ} \mathrm{C}$ の熱処理で は変化しなかったものの, $200{ }^{\circ} \mathrm{C}$ から徐々に低下し, $300{ }^{\circ} \mathrm{C}$ では $90 \mathrm{HV} 1$ となった。図 4 には，DLC 成膜後の母材 A7075 の硬さも示しているが, DLC 成膜前後での硬さの変化はほ とんどないことから，UBMS の DLC 成膜過程における温度 上昇による基材の軟化は生じないことが示された。

3. 3 Ni-P / DLC 複合皮膜のスクラッチおよびロック ウェル圧痕試験

DLC 膜をはじめとしたハードコーティングの密着性評価

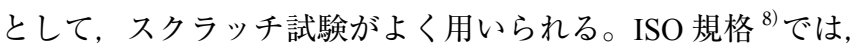

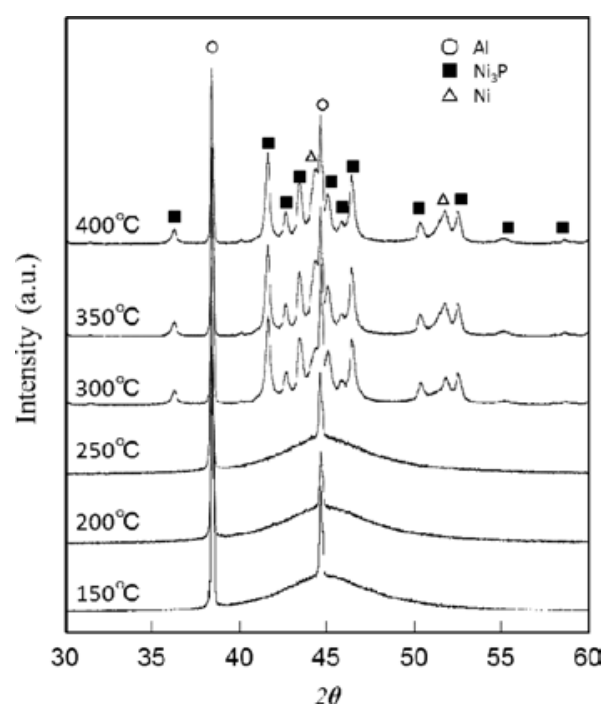

図３＼cjkstart熱処理した Ni-P 膜の結晶構造

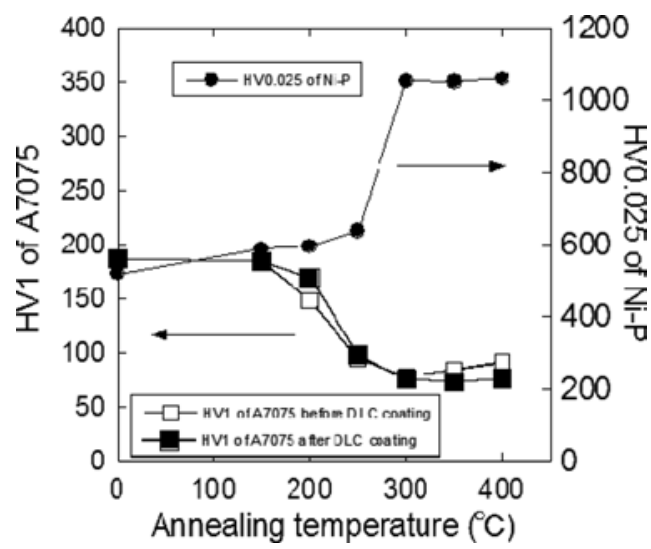

図 4 Ni-P 膜および A7075 基材硬さの熱処理温度変化

図 2 Ni-P/DLC 複合膜の構成図 

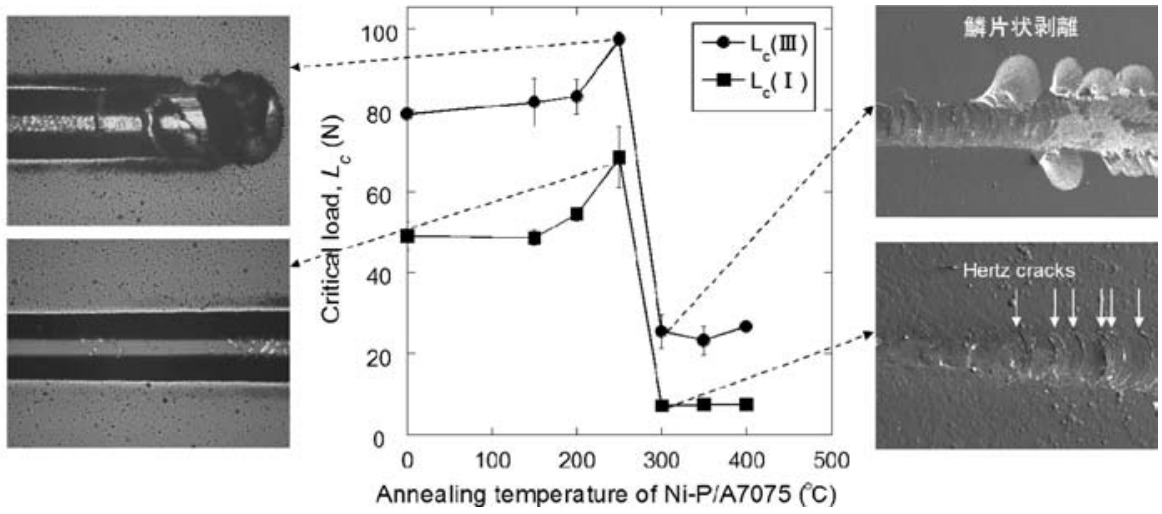

図 5 Ni-P / DLC 複合膜のスクラッチ試験結果

基板硬さが HRC45 ～ 65 を用いることと規定がある。した がって，軟質なアルミニウム合金を基材として用いた場合， 規定を満たさないが基材が変形し過ぎるので，より過酷な損 傷評価となる。ロックウェル圧痕試験(HRC 押し込み試験) は, 密着性や膜質などを知ることが可能で，その簡便さから現場 での品質管理に常用されている。ドイツ技術者協会に規格 ${ }^{9)}$ があり, 定量的ではないものの, 皮膜の損層状況に応じて 6 段階 (HF1 6)で評価するよう規定されている。

Ni-P / DLC 複合皮膜のスクラッチ試験結果を図 5 に示す。 Lc-I は皮膜の亀裂をまた Lc-III は下地の Ni-P が見られ DLC が全て剥離した荷重を示す。As depo 試料では, $50 \mathrm{~N}$ 付

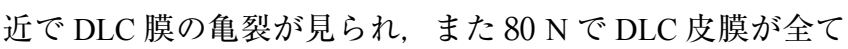
剥離した。剥離荷重 Lc は, 熱処理温度の増加とともに増加し, 250 ㅇで, Lc-I : 68 N, Lc-III : 93 N と最大值を示した。しか し，300 ${ }^{\circ} \mathrm{C}$ 以上の熱処理では，Lc-I, III ともに劇的に低下した。 $300{ }^{\circ} \mathrm{C}$ 以降の試料では, スクラッチ初期から DLC 薄膜の亀 裂および剥離が生じ，また鱗片状の剥離が観察されるように なった。クラックが観察された $300{ }^{\circ} \mathrm{C}$ 熱処理試料の $10 \mathrm{~N}$ 付 近の断面 SIM 像を図 6 に示す。Ni-P膜内部には，表面に進 展した垂直方向の亀裂のみならず，水平方向にもラテラルク ラックが発生し，亀裂が進展していることがわかった。これ は熱処理による Ni-P 膜の高硬度化にもとづく鞎性の著しい 低下によると考えられる。

次に, HRC 押し込み試験後の SEM 写真を図 7 に示す。熱 処理温度の増加とともに, 基材の軟化により圧痕形状が大き

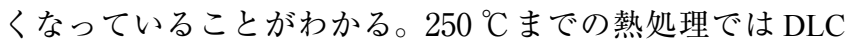
皮膜の剥離は全く見られなかったが， $300{ }^{\circ} \mathrm{C}$ 以上では圧痕周 辺部に大きな亀裂が見られるとともに，DLC 皮膜が剥離した。 これは，基材変形に対するDLC 皮膜の追随性が悪いという ことよりも，スクラッチ試験の結果と同様に Ni-P 膜の靸性 の低下にともなうへルツおよびラテラルクラックの進展によ る剥離であると考えられる。

\section{4 Ni-P / DLC 複合皮膜のマイクロインデンテーション}

インデンテーション技術は, 微小領域および薄膜化のニー ズに対応するために近年目覚ましい発展を遂げてきた。サブ ミクロンオーダーの膜厚しかない薄膜について, 硬さやヤン グ率といった機械的特性を知ることのできる唯一のツールで あるが,ささにハードコーティングへの押し込みでは, 密着 性に関わる情報を得ることもできる。スクラッチ試験やロッ
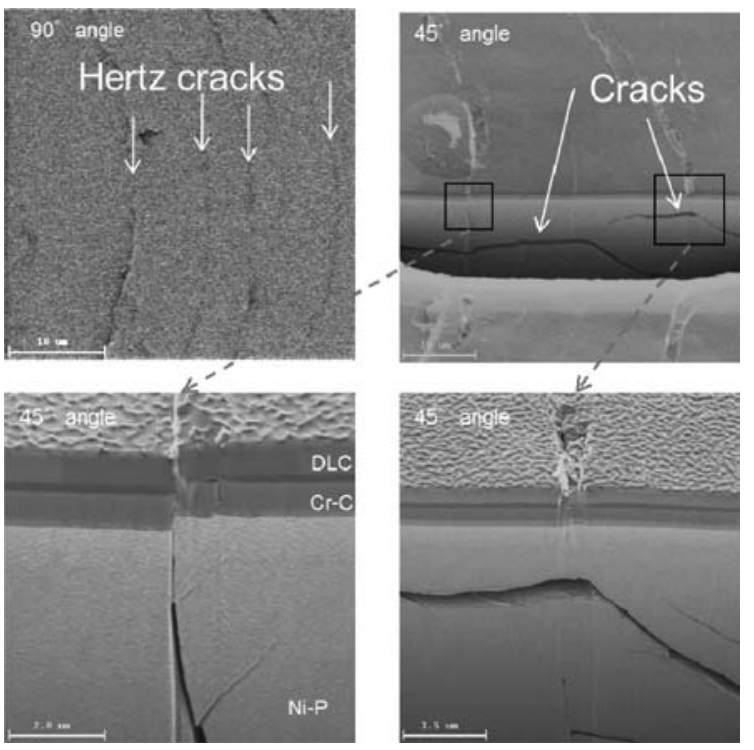

図 6 Ni-P / DLC 複合膜のスクラッチ痕直下の断面 SIM 像

クウェル圧痕試験は先端曲率の $200 \mu \mathrm{m}$ のダイヤモンド圧子 で数十 $\mathrm{N}$ オーダーの荷重を印加し, 皮膜の損傷を評価するの に対し，マイクロインデンテーションではせいぜい数 $\mathrm{N}$ 程度 までの荷重領域であるが, 先端の鋭利なビッカースや Berkovich 型のダイヤモンド圧子を用いるために, 接触面積は 小さく, 浅い領域で局所的に皮膜と基板界面に最大せん断応 力を発生させることができる。したがって, 界面との密着力 が不十分な場合, 得られる荷重 - 変位曲線に Pop-in と呼ばれ るシグナルが現れるとともに，皮膜の剥離が観察される ${ }^{10)} 。$

Berkovich 型ダイヤモンド圧子を最大荷重 $1 \mathrm{~N}$ での押し込 み試験を行った結果を図 8 に示す。As-depo 試料は連続した 荷重 - 変位曲線を描いており，明瞭な三角錐形状の圧痕が観 察され, 圧痕内部に圧痕三角形の辺と平行した亀裂(リップ ルクラック)が見られた。一方, $300{ }^{\circ} \mathrm{C} て ゙$ 熱処理した試料は, 押し込み深さが $2 \mu \mathrm{m}$ 程度で, DLC 膜の剥離による Pop-in が 見られ, DLC 膜の低い密着性が示された。このような Popinにともなう皮膜の剥離は $300{ }^{\circ} \mathrm{C}$ 以上の熱処理をした試料 では見られたが， $150,200,250{ }^{\circ} \mathrm{C} て ゙$ 熱処理した試料では生じ ることはなかった。この剥離はスクラッチで見られた剥離形 態と異なった。Pop-in が見られた試料直下の断面 SIM 観察 では，スクラッチで見られたような Ni-P膜の亀裂は観察さ 

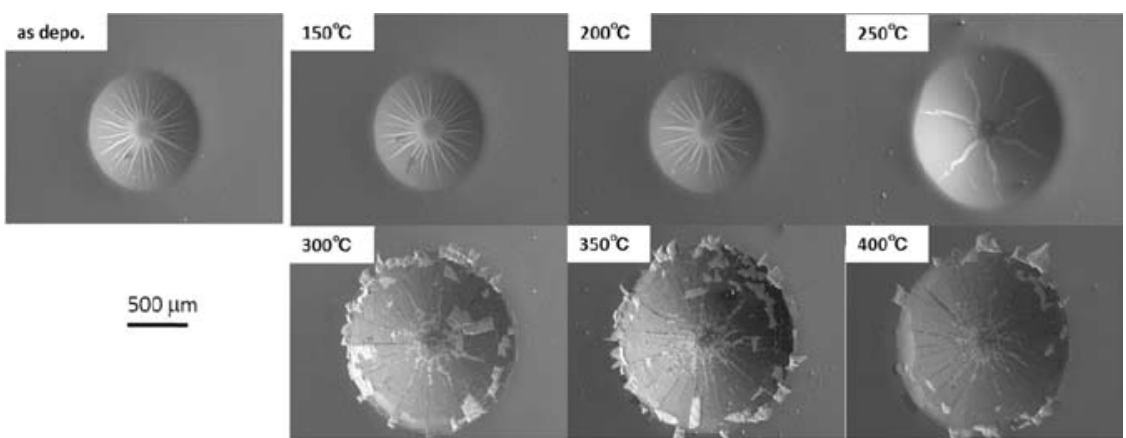

図 7 Ni-P / DLC 複合膜のロックウェル圧痕試験後の SEM 像
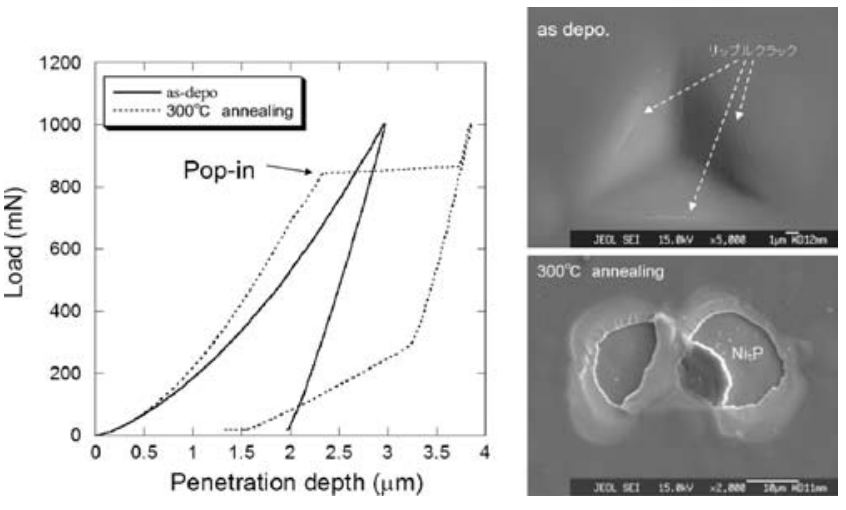

図 8 Ni-P / DLC 複合膜のマイクロインデンテーション結果

れず, DLC 膜のみが剥離していることがわかった。したがっ て, Ni-P 膜が熱処理により結晶化し, 高硬度かつ弾性変形 能が低下することにより，せん断応力が Ni-P 膜と DLC 膜界 面に集中したため, DLC 膜が剥離したと考えられる。この ような Pop-inをともなう損傷が生じる場合，摺動部材にお いて微細な硬質異物の混入により，数ミクロン程度ではある が DLC 膜が損傷しうることを示しており，この微細な損傷 が起点となって大規模な剥離に進展する恐れがあるので十分 注意する必要がある。

\section{4. おわりに}

東日本大震災以降，省資源・省エネルギーはものづくりに おいても大きな潮流となっている。たぐいまれなる高機能性 を持つ DLC 膜の適用分野の拡大に大きな期待を寄せずには いられない。

本稿では，アルミニウム合金に DLC 膜を適用する場合に は中間層の導入による複合処理化が不可欠であり, 中間層の 膜質や基材の変化が密着性に及ぼす影響について Ni-P めっ きを例として示した。本稿で取り上げた組み合わせ（基材： A7075-T6, 中間層: $21 \mu \mathrm{m}$ 厚 Ni-P, 皮膜 : $2 \mu \mathrm{m}$ 厚 DLC + $\mathrm{Cr}$ 膜)に扔いて, 密着性が最も良くなったのは熱処理温度が $250{ }^{\circ} \mathrm{C}$ の場合であった。しかしながら，A7075-T6 基材では， $200{ }^{\circ} \mathrm{C}$ の熱処理でも基材の軟化が避けられないことから, 実 製品に適用する場合には熱処理しないか $200{ }^{\circ} \mathrm{C}$ 未満の熱処理 に限定される。いいかえれば，DLC 膜は基材変形の追随性 は他の硬質膜と比べて良いので，軟質な基材の場合でも中間 層の膜質抒よび膜厚を最適化することによって高機能な DLC 膜を適用しうると考えられる。
DLC 膜のみならずハードコーティングの密着性の評価は, 界面の密着強度のみを定量評価したいと要求されることがあ るが，現状はスクラッチ試験やロックウェル圧痕試験など外 部応力に対する損傷評価しかない。しかし，実製品における 剥離トラブルは，そのほとんどが外部応力による損傷が原因 である。ただし，スクラッチ試験やロックウェル圧痕試験は ある特定の外力に対する損傷を見ているに過ぎない。これに 対してマイクロインデンテーションは, Berkovich 型やビッ カース型あるいはロックウェル型など異なる接触状態で荷重 を任意に変化させることができ，実使用環境で見られる損傷 状態に近い応力状態を再現することが可能である。また, Popin なとの皮膜損傷をその発生荷重・変位として定量的に評価 できる。こうした損傷を FIB などによる断面観察を行うことで, その損傷が中間層にあるのか基材にあるのか, 膜質にあるの かを明らかにし，損傷メカニズムを考察していく必要がある。

以上から，アルミ材のような軟質材料への高機能 DLC 膜 を適用する場合は，中間層の導入による複合処理化が不可欠 であり，製品の使用環境に応じた皮膜損傷を予測し，その損 傷メカニズムを解明しながら複合膜処理膜を最適化していく ことが重要である。

(Received January 10, 2012)

\section{文献}

1 ）池永 勝, 鈴木秀人；ドライプロセスによる超硬質皮膜の原理と 工業的応用, p.58 (日刊工業新聞社, 2000).

2 ) 國次真輔,野村博郎; 表面技術, 60, 527 (2009).

3 ) 野村博郎, 鈴木史人, 横瀬敬二, 戸石光輝 ; 第118回講演大会講演 要旨集, p.114（表面技術協会, 2008).

4 ) 國次真輔, 日野 実, 野村博郎, 佐藤秀昭 ; 第116回講演大会講演 要旨集, p.148 (表面技術協会, 2007).

5 ) 加納 眞, 熊谷正夫, 堀内崇弘, 吉田健太郎; 神奈川県産業技術七 ンター報告, 16, 44 (2010)

6 ) 國次真輔, 日野 実, 野村博郎; 第118回講演大会講演要旨集, p.112（表面技術協会, 2008)

7 ) 電気鍍金研究会編 ; 無電解めっきの基礎と応用, p.37 (日刊工業 新聞社, 2004).

8 ) ISO20502 ; Fine ceramics (advanced ceramics, advanced technical ceramics)-Determination of adhesion of ceramic coatings by scratch testing (2005).

9 ) VDI 3824 ; Quality assurance of PVD and CVD hard coatings Part 4 : Inspection planning for hard coatings (2001).

10) J. Qi, K. H. Lai, C. S. Lee, I. Bello, S. T. Lee, J. B. Luo, S. Z. Wen,; Diamond and Related Materials, 10, 1833 (2001). 